\title{
Joggyakorlat
}

\section{BAgdi KatALIN* \\ A sztrájkhoz való jog az Emberi Jogok Európai Bíróságának gyakorlatában}

\author{
sztrájkjog - EJEE 11. cikk - Emberi Jogok Európai Bírósága - \\ Európai Unió Bírósága
}

A sztrájkhoz való jog a munkaharc egyik formájaként a kollektív munkajog területének kiemelkedően fontos és sokat tárgyalt kérdésköre, különösen korlátozhatóságának terjedelme miatt. A munkajogviszony egyik meghatározó jellemzője, hogy a munkáltató és a munkavállaló között hierarchikus viszony alakul ki (függő munka), amelyben az utóbbi alárendelt helyzetben van. A munkavállaló személyi és gazdasági függése a munkáltatótól előbbi gazdasági és szociális kiszolgáltatottságát eredményezi, ami a felek között a polgári jogra jellemző egyensúlyi helyzetet megbontja, és így egyfajta eröbeli egyenlőtlenség alakul ki köztük. Ezen helyzetek kiegyensúlyozására szolgáló eszközök egyike a sztrájkhoz való jog, amely lényegében a munkavállaló ellenállási joga, ${ }^{1}$ „a kollektív önrendelkezés egyik kifejező formája”. ${ }^{2}$

A sztrájkhoz való jogra vonatkozó szabályanyag többszintü: nemzetközi, regionális és európai ${ }^{3}$ szinten kerültek meghatározásra a fontosabb szabályok, amelyekre a nemzeti jogalkotónak is tekintettel kell lennie. A jelen témakör szempontjából a regionális szinten megjelenő Európa Tanács, illetve az annak keretében megalkotott Emberi Jogok Európai Egyezménye (EJEE) bír jelentőséggel. A Lisszaboni Szerződés hatálybalépése óta pedig megnyílt a lehetőség az Európai Unió (EU) előtt, hogy csatlakozzon az EJEE-hez, aminek a megvalósulása azt is jelentené, hogy az Emberi Jogok Európai Bíróságának (EJEB) gyakorlata válna irányadóvá az uniós intéz-

* Dr. Bagdi Katalin PhD-hallgató, Debreceni Egyetem Állam- és Jogtudományi Kar Agrárjogi, Környezetjogi és Munkajogi Tanszék, bagdi.katalin31@gmail.com.

1 KAJTÁR Edit: Magyar sztrájkjog a nemzetközi és az európai szabályozás fényében. PhD-értekezés, Pécs, 2011, 22.

2 KAJTÁR: i. m., 19.

3 Ez alatt az Európai Unió vonatkozó szabályanyagát, illetve az Európai Unió Bíróságának esetjogát kell érteni. 
mények, így az Európai Unió Bírósága (EUB) számára is. Erre a most már nem csak elméleti lehetőségre, valamint a gazdasági és szociális jogok emberi jogi szempontú vizsgálatának terjedésére tekintettel érdemesnek tartjuk elemezni, hogyan alakult az EJEB gyakorlata a sztrájkjog tekintetében, továbbá azt, hogy az EJEB és az EUB gyakorlata összhangban van-e egymással.

\section{A sztrájkhoz való jog mint alapjog}

Nincs egységesen elfogadott definíciója a sztrájknak, ám az lényegében „...valamely bérből, fizetésből élö munkacsoport közös megegyezése a munkatevékenység beszüntetésére annak érdekében, hogy egy vagy több vállalkozó üzemének müködését megakadályozzák, és így a munkáltatóra vagy harmadik személyre nyomást gyakoroljanak”. ${ }^{4}$ Egy másik fogalom szerint a sztrájk „...a munkavállalók többségének tervszerü és közösen végrehajtott ideiglenes munkabeszüntetése a munkajogviszony elözetes felmondása nélkül". ${ }^{5}$ Jellegéhez tehát hozzátartozik, hogy közös és szabad elhatározásból történő munkabeszüntetés, amely mindig ideiglenes, mivel a munkavállalók végső célja az, hogy a munkaharc beszüntetését követően (akár elérték céljukat, akár nem) a munkát újból felvegyék. ${ }^{6}$ Sztrájk csak a munkavállalók gazdasági és szociális érdekeinek előmozdítása érdekében kezdeményezhető, a kizárólagosan politikai jellegű sztrájk tilos. Mivel a munkabeszüntetés a munkáltató számára jelentős kárt, illetve hátrányt okozhat, a sztrájk csak végső eszközként, ultima ratio jelleggel alkalmazható. A sztrájkjog alkalmas lehet arra, hogy kiegyenlítse az erőviszonyokat a munkáltató és a munkavállalók közötti alkufolyamatban. A munkavállalóknak és képviselőiknek szüksége van olyan eszközre, melynek révén kényszeríteni tudják a munkáltatót arra, hogy meghallgassa kéréseiket, követeléseiket. A sztrájkjog révén képesek „megfenyegetni” a munkáltatót a munka megzavarásával, abbahagyásával, amely adott esetben a munkáltató működésére, teljesítményére is kihatással lehet. Ez legalább annak az elérésére alkalmas, hogy a munkáltató meghallgassa követeléseiket, adott esetben pedig beleegyezzen azokba - ily módon ugyanis meg tudja akadályozni a munkabeszüntetést, vagy minimalizálni az általa okozott kárt. Sztrájkjog hiányában a munkáltató egyszerüen visszautasíthatja a munkavállalók és szakszervezetek követeléseit mindenféle következmény nélkül, ${ }^{7} \mathrm{~s}$ így lényegében a szakszervezetek elvesztik alkupozíciójukat a munkáltatóval szemben. ${ }^{8}$ Fő szabály szerint a munkavállalók kollektíváját (valamennyi munkavállalót

4 PRUgBerger Tamás-NÁdAs György: Európai és magyar összehasonlitó munka- és közszolgálati jog. CompLex, Budapest, 2014, 621.

5 Kıss György: Munkajog. Osiris Kiadó, Budapest, 2005, 496.

6 Prugberger-Nádas: i. m., 621.

7 Davies, A. C. L.: Perspectives on Labour Law. Second edition, Cambridge University Press, Cambridge, 2009, 220.

8 A 2012. évi Munka Törvénykönyve által bevezetett normatív hatályú üzemi megállapodás kapcsán is az a szakirodalom álláspontja, hogy mivel az üzemi tanács tagjai semleges magatartásra kötelesek üzemi tanácsi feladataik ellátása során, s így nem is sztrájkolhatnak e minőségükben, lényegében nincsenek alkupozícióban, amely hiányában nem is képes az üzemi tanács a munkavállalók számára elönyös megál- 
vagy azok egy csoportját) illeti meg a sztrájkhoz való jog, ${ }^{9}$ ám a tekintetben, hogy végső soron ki gyakorolhatja azt, a szakszervezet vagy a kollektíva, már a vonatkozó nemzetközi egyezményektöl és nemzeti szabályozástól függ.

Több, a munkavállalókat és munkáltatókat megillető jogosultsággal foglalkozó nemzetközi egyezményben ${ }^{10}$ is rögzítésre került - és így a nemzetközi szervezetek gyakorlatában is elismerést nyert - a sztrájkhoz való jog, valamint a különböző munka- és szociális jogok egyre inkább alapjogi elismerést nyernek, ezért tisztázni szükséges, hogy a munkaharc egyik legjelentősebb típusának tekinthető sztrájkjog maga is alapjognak tekinthető-e, avagy „...kifejezetten a magánautonómia sajátos munkajogi megfelelöjeként a koalíciós szabadság egyik megjelenési formája"11 maradt. Ebben a tekintetben az figyelhető meg, hogy a sztrájkjog ma már nem kizárólag a munkajog keretén belül értelmezendő jogosultság, hanem egyre inkább alapvető emberi (állampolgári) joggá válik, ${ }^{12}$ amely tendencia álláspontunk szerint elöremutató.

Az alapvető jogok klasszikus, generációk szerinti csoportosítását alapul véve az látható, hogy a sztrájkjog második generációs alapjog, azaz a gazdasági, szociális és kulturális jogok közé tartozik, ${ }^{13}$ amelyeket ma még nem tekintenek a polgári és politikai szabadságjogokkal egyenrangúnak. Míg az első generációs jogok kapcsán elvben az állam negatív magatartásra köteles, azaz el kell ismernie és tiszteletben kell tartania azokat, addig a gazdasági, szociális és kulturális jogok elismerése és az érvényesülésüknek előmozdítására tett lépések nagysága jelentős részben az adott állam fejlettségétöl és gazdasági helyzetétöl függ. ${ }^{14}$ Ez talán következhet abból a tényből, hogy a polgári és politikai jogok tekintetében jellemzően elegendő, ha az állam csupán elismeri a jogok létezését, és minél kisebb mértékben avatkozik bele azok gyakorlásába, $\mathrm{s}$ így ez a negatív kötelezettség az állam számára nem jár különösebb megterheléssel. Ezzel szemben azonban a második generációs alapjogok tekintetében már az állam pozitív magatartásra köteles, azaz elő kell mozdítania azok érvényesülését, amely e jogok sajátosságaiból fakadóan akár anyagilag

lapodás megkötésére. [Lásd erröl többek között: Gyulavári Tamás (szerk.): Munkajog. ELTE Eötvös Kiadó, Budapest, 2014, 457-460; KÁRTYÁs Gábor: Kollektív szerződés az üzemi tanáccsal, avagy a csizma az asztalon. http://www.hrblog.hu/azujmt/2011/12/22/kollektiv-szerzodes-az-uzemi-tanaccsal-avagy-csizmaaz-asztalon/ (2016. 01. 31.); Kun Attila: Átrendeződés a kollektív munkajogban - szakszervezetek kontra üzemi tanácsok az új Munka Törvénykönyve tükrében. In: Antalóczy Péter (szerk.): Hagyomány és érték: állam- és jogtudományi tanulmányok a Károli Gáspár Református Egyetem fennállásának 20. évfordulójára. Budapest, Károli Gáspár Református Egyetem Állam- és Jogtudományi Kar, 2013, 304-312.] Ugyanez igaz a szakszervezetre is: sztrájkjog hiányában képtelenek lesznek a munkavállalók számára jobb munkakörülmények kiharcolására, végső soron a szervezet céljának elérésére.

9 KAJTÁR: i. m., 12.

10 Például az Európai Szociális Chartában (1961) és az ENSZ 1966-os Gazdasági, Szociális és Kulturális Jogok Nemzetközi Egyezségokmányában vagy a munkavállalók alapvetö szociális jogairól szóló Közösségi Chartában.

11 Kiss (2005): i. m., 493.

12 Kiss György szerint is a sztrájkjog a „klasszikus munkáltató-munkavállaló pozicionáltsághoz kötött jogból egyre inkább állampolgári alapjoggá alakul át”. Kıss (2005): i. m., 494.

13 Van olyan álláspont, amely szerint politikai, gazdasági, szociális jogok megkülönböztetés helyett helyesebb lenne a szociális szférára kiható alapvető jogok fogalom bevezetése. KAJTÁR: i. m., 19.

14 Lásd még RAB Henriett: A nyugdijbiztositási ellátások fenntarthatóságának jogi garanciái. HVG-ORAC Lapés Könyvkiadó Kft., Budapest, 2012, 112-113. 
is megterhelö lehet, s ezért is függ a második generációs jogok elismerése az adott állam gazdaságának fejlettségétől. ${ }^{15} \mathrm{Az}$ alapvető jogok univerzalitásával azonban nem egyeztethetö össze ez a különbségtétel, s maga az ENSZ is azon az állásponton van, hogy bár az első és második generációs alapjogok két külön egyezményében kerültek elismerésre ${ }^{16}$ valójában ezek a polgári és politikai szabadságjogok, valamint a gazdasági, szociális és kulturális jogok egymástól elválaszthatatlanok, és azonos státuszt élveznek. ${ }^{17} \mathrm{Az}$ utóbbi évtizedekben változott az alapvető emberi jogokkal kapcsolatos gondolkodásmód, bizonyos gazdasági és szociális jogok az első generációs jogokkal szinte azonos védelmet nyertek azzal, hogy egyre több második generációs jog esetében elismerték a polgári és politikai jogokból való levezethetőségüket. Mivel azonban ez az elismerés nem automatikus, hanem csak egyes jogok tekintetében történik meg a nemzetközi szervezetek és bíróságok gyakorlatában, ezért bizonyos gazdasági és szociális jogok csak egy hosszabb folyamat eredményeként válnak az első generációs jogokkal egyenrangú alapjogokká.

Annak ellenére, hogy a sztrájkhoz való jog a második generációs alapjogok között található meg, nem teljesen egyértelmú, hogy valóban ebbe a csoportba tartozik-e. A szabadságjogokhoz viszi közelebb az a vonása, amely szerint az állam szerepe a sztrájkjog tekintetében inkább negatív, vagyis elsősorban a jog gyakorlásának tiszteletben tartására kell fókuszálnia, és ehhez képest a pozitív kötelezettségek inkább csak másodlagosan jelennek meg. ${ }^{18} \mathrm{Nem}$ tekinthető azonban valódi szabadságjognak sem, mivel azokkal ellentétben a sztrájkjog mindig célhoz kötött, kizárólag rendeltetésszerüen gyakorolható, valamint ab ovo csak korlátokkal érvényesül, illetve bizonyos (nagyon kivételes) helyzetekben ${ }^{19}$ akár teljes mértékben elvonható. ${ }^{20}$

A nemzeti szabályozástól függően a sztrájkjog alapvetően a munkavállalók egy csoportját vagy a szakszervezetet illeti meg, ám a gyakorlatban jellemzően az utóbbi fogja azt gyakorolni. ${ }^{21}$ Ily módon „a munkaharchoz való jog [...] levezethető az általános, tradicionális, első generációs alapjogokból". ${ }^{22}$ Mivel a szakszervezet a munkavállalóknak egyesülési szabadság alapján létrehozott érdekképviseleti szerve, ily módon a sztrájkhoz való jog kapcsolódik az egyesülési és gyülekezési joghoz mint első generációs alapjogokhoz. ${ }^{23}$ Sőt tulajdonképpen azoktól elválaszthatatlan, ${ }^{24}$

15 Bizonyos kiadások azonban az első generációs jogok biztosítása esetén is felmerülnek, mint például a választási eljárás lebonyolításának költségei.

16 1966-ban került megalkotásra az ENSZ Polgári és Politikai Jogok Nemzetközi Egyezségokmánya, valamint a Gazdasági, Szociális és Kulturális Jogok Nemzetközi Egyezségokmánya.

17 Davies (2009): i. m., 41.

18 RÁcz Zoltán: A sztrájkjog megítélése az Alaptörvény tükrében. Publicationes Universitatis Miskolciensis, Sectio Juridica et Politica, Tomus XXX/2. (2012), 570; Zemplényi Adrienne (szerk.): Sztrájkjogi projekt. ÁJOB Projektfüzetek, Budapest, OBH, 2010/4, 19; JuHÁsz Zoltán: Sztrájk és felelősség. Jogtudományi Közlöny, 2010/5, 239.

19 Például a rendvédelmi szervek vagy a honvédség tagjai számára jellemzően tilos a sztrájk.

20 RÁCZ: i. m., 570; ZemplénYI: i. m., 19; JuHÁSz: i. m., 239.

21 KAJTÁR: i. m., 19.

22 Kıss György: Alapjogok kolliziója a munkajogban. Justis, Pécs, 2010, 233.

23 Létezik olyan vélemény, amely szerint a sztrájkhoz való jognak nemcsak a gyülekezési és egyesülési jog az előfeltétele, hanem a véleménynyilvánítási jog is. RÁcz: i. m., 570.

24 KaJTÁR: i. m., 19. 
hiszen a sztrájkjogot kizárólag az a szakszervezet gyakorolhatja, amelyik az egyesülési szabadság alapján jött létre. ${ }^{25}$ Közös vonása a sztrájkjognak és az egyesülés szabadságának, hogy alapvetően az egyéneket megillető alapjogok, $s$ ezen egyének szabadon dönthetnek arról, hogy csatlakozni kívánnak-e az adott entitáshoz/ eseményhez vagy inkább távol kívánnak maradni attól. A sztrájkjog tehát nem originális, hanem az egyesülési szabadságból származtatott alapjog. ${ }^{26}$ Ebből fakadóan bár a sztrájkjog érezhetően egyre inkább állampolgári joggá alakul át, ${ }^{27}$ jellemzően még mindig az első generációs alapjogokból vezetik le, ezzel igazolva alapjogi jellegét, egyúttal azonban gátat szabva azon törekvésnek, hogy a polgári és politikai szabadságjogokkal azonos szintú elismerést kapjon, ami pedig nemzetközi bíróságok előtt történő kikényszeríthetőségének lehetőségét mindenképpen csökkenti.

\section{Az Emberi Jogok Európai Egyezménye és a sztrájkjog}

Az Európai Szociális Chartában a béralkuhoz való jog részeként került elismerésre a dolgozók és a munkaadók joga az érdekkonfliktusok esetén történő kollektív fellépésre, amibe bele kell érteni a sztrájkhoz való jogot is. ${ }^{28} \mathrm{~A}$ Módosított Európai Szociális Charta változatlanul tartalmazza ezt a rendelkezést. ${ }^{29} \mathrm{~A}$ megfogalmazás tükrözi a sztrájkjognak azt a nemzetközi jogi megítélését, amely szerint e jog korlátozott, mégpedig azért, mert jellemzően más (munkavállalói) jogok érvényesülésének elömozdítása a célja. ${ }^{30}$

Ezek az egyezmények ugyan elismerik a sztrájkhoz való jogot, ám nem bírnak olyan védelmi mechanizmussal, amely e jog kikényszerítését lehetővé tenné. Az Európai Szociális Chartával és a Módosított Európai Szociális Chartával ellentétben az Európa Tanács másik, az előzőeknél nagyobb jelentőséggel és hatékonyabb védelmi mechanizmussal rendelkező egyezménye, az EJEE nem nevesíti a sztrájkhoz való jogot mint védendő alapjogot. Ez azonban nem jelenti azt, hogy az EJEE valamely rendelkezésébe a sztrájkjog ne volna beleérthető, hiszen - ahogy arról korábban már volt szó - a sztrájkhoz való jog szoros kapcsolatban áll az egyesülési szabadsággal, amely így oly módon interpretálható, hogy abból kiolvasható legyen a sztrájkhoz való jog. Az EJEE értelmében mindenkinek joga van a békés célú gyülekezés szabadságához és a másokkal való egyesülés szabadságához, beleértve érdekei védelmében a szakszervezetek alapítását és az azokhoz való csatlakozásnak a jogát. ${ }^{31}$ Ez alapján tehát érdekeik védelme érdekében a munkavállalók is jogosultak szervezetek létrehozására, valamint ilyen szervezetekhez történő csatlakozásra. Az azonban, hogy az előbb említett szakszervezeti jogokon túl az EJEE 11. cikk

\footnotetext{
25 Megjegyzendő, hogy a sztrájkjog gyakorlása ott kötődik ilyen szorosan az egyesülési szabadsághoz, ahol kizárólag a szakszervezet kezdeményezheti a kollektív fellépés ezen formáját.

26 KIss (2005): i. m., 494.

27 Rácz: i. m., 570.

28 Európai Szociális Charta (1961), 6. cikk (4) bekezdés.

29 Módosított Európai Szociális Charta (1996), 6. cikk (4) bekezdés.

30 RÁcz: i. m., 571.

31 EJEE 11. cikk (1) bekezdés.
} 
(1) bekezdésében a sztrájkhoz való jog is beleértendő-e, sokáig nem volt teljesen egyértelmü, s maga az EJEE rendelkezéseit interpretáló EJEB sem tekintett úgy a sztrájkjogra, mint az egyesülési szabadságból értelmező, és így az EJEE által védendő alapjogra. Az EJEB gyakorlatában elsősorban a sztrájkjog elismerésével és korlátozásával, valamint a szolidaritási sztrájkkal kapcsolatos kérdéskörök merültek fel, így a következőkben ezek elemzésére kerül sor.

\subsection{Az Emberi Jogok Európai Bíróságának gyakorlata}

A Bíróság elé rendkívül kevés olyan eset kerül, amely kifejezetten a sztrájkjogról szól, ezért igen szük az ezzel kapcsolatos esetjog, aminek részben az az oka, hogy az EJEE megalkotásakor a kor szellemének megfelelően az első generációs jogok védelmére törekedtek a szerződő államok. Az EJEE 11. cikk (1) bekezdése említi a pozitív koalíciós szabadságot, azaz a szakszervezet-alapítás és a szakszervezetekhez való csatlakozás jogát, amit az egyesülési szabadság egy speciális aspektusaként, különleges formájaként így védelemben részesít. ${ }^{32}$ Ám ezt a rendelkezést az EJEB egészen az 1970-es évekig ${ }^{33}$ rendívül szüken értelmezte, mivel álláspontja szerint a szakszervezetek jogaival a szintén az Európa Tanács által létrehozott Európai Szociális Charta foglalkozik. ${ }^{34}$ Ahogy aztán a gazdasági és szociális jogok alapjogi megközelítése egyre inkább teret nyert, úgy változott meg az EJEB gyakorlata, és úgy bővült az EJEE által védelemben részesített szakszervezeti jogok, illetve a munkavállalók kollektívája számára biztosított jogok köre, s így elötérbe kerülhetett a sztrájkhoz való jog mint az EJEE és az EJEB által szintén védendő alapjog vizsgálata is.

Az EJEE 11. cikke biztosítja a szakszervezeti tag munkavállalók érdekeinek védelmére a szakszervezeti akciók szabadságát, amelyek lebonyolítását a részes államok kötelesek engedélyezni és lehetővé tenni, ám annak meghatározása, hogy ezt a célt milyen eszközök révén biztosítják, már az egyes államok döntési jogkörébe tartozik. ${ }^{35} \mathrm{Az}$ EJEB ezért sokáig azon az állásponton volt, hogy az EJEE nem biztosítja a sztrájkhoz való jogot, csupán egy általános kötelezettséget foglal magában, amelynek lényege az, hogy a részes államoknak biztosítaniuk kell egy olyan mechanizmust, amely a szakszervezetek érdekvédelmi tevékenységét lehetővé teszi és biztositja, ám ennek módját nem kötötte ki. ${ }^{36} \mathrm{Az}$ EJEB elismerte ugyan, hogy a sztrájk az egyik legfontosabb és leghatékonyabb eszköz a munkavállalói érdekek

32 National Union of Belgian Polica kontra Belgium ügy, 1975. október 27-i itélet (ügyszám: 4464/70), 38. pont; Swedish Engine Drivers' Union kontra Svédország ügy, 1976. február 6-i itélet (ügyszám: 5614/72), 39. pont; Schmidt and Dahlström kontra Svédország ügy, 1976. február 6-i ítélet (ügyszám: 5589/72), 34. pont; Demir and Baykara kontra Törökország ügy, 2008. november 12-i ítélet (ügyszám: 34503/97), 109. pont.

${ }_{33}$ Az 1970-es évektöl kezdődően került sor a munka- és szociális jogok emberi jogi aspektusból történő vizsgálatára [DAVIES (2009): i. m., 38.]. Minden valószínűség szerint ez a szemléletváltás érhető tetten a Bíróság gyakorlatában is.

34 Swedish Engine Drivers' Union ügyben hozott ítélet, 39. pont.

35 Swedish Engine Drivers' Union ügyben hozott ítélet, 36. pont.

36 Schmidt and Dahlström ügyben hozott ítélet, 36. pont. 
védelmére ${ }^{37}$ ám még a 2000-es évek elején is azt vallotta, hogy e védelem más eszközök (például kollektív szerződés ${ }^{38}$ ) révén is biztosítható. ${ }^{39}$ Mindez azt jelentette, hogy a sztrájkhoz való jog nem képezi szükségszerü és elválaszthatatlan részét a koalíciós szabadságnak, s így az EJEE 11. cikk (1) bekezdése nem is védi kifejezetten azt, hanem a részes államokra bízza annak eldöntését, hogy milyen eszközöket ad a szakszervezetek kezébe annak érdekében, hogy képesek legyenek érdekvédelmi tevékenységük ellátására (amelynek az EJEB szerint csupán az egyik, de nem az egyetlen eszköze a sztrájk).

A munkavállalók azonban éppen azért alakítanak szakszervezeteket, illetve azért csatlakoznak hozzájuk, hogy azok a számukra biztosított jogosítványok révén megvédjék a munkavállalók gazdasági és szociális érdekeit, amely védelem nem lehet teljes és hatékony a kollektív alkuhoz való jog, valamint a sztrájkhoz való jog biztositása nélkül. ${ }^{40}$ Mivel a sztrájk a munkavállalói kollektíva lényegében egyetlen hatékony nyomásgyakorló eszköze érdekei érvényesítésére a munkáltatóval szemben, semmilyen „egyéb eszköz” - amelyekre az EJEB korábbi ítéleteiben utalt - nem lehet alkalmas ezen védelem biztosítására, mivel azok nem képesek akkora hatást elérni, mint a sztrájk. Ezért az EJEB által hivatkozott egyéb eszközök bár szükségesek, ám a sztrájknak csupán kiegészítői lehetnek, nem pedig alternatívái. Ezért a szakszervezetek alakításához és az azokhoz való csatlakozás jogához elválaszthatatlanul hozzákapcsolódik a sztrájkhoz való jog, mivel a munkavállalók egyesülési és gyülekezési szabadsága alapvetően e révén gyakorolható. Amennyiben erre a szakszervezeteknek nincs lehetősége, úgy a szakszervezet-alapítás, valamint a szakszervezethez történő csatlakozás joga lényegében kiüresedik. ${ }^{41}$ Mindezzel az EJEB is tisztában volt, ezért különös, miért döntött mégis a sztrájkjog elismerése ellenében. Továbbá éppen ezért az EJEE által biztosított egyesülési szabadságba bele kellene tartozzon a koalíciós szabadság mellett a sztrájkjog is. ${ }^{42}$

Még a 2006-os Demir and Baykara ügyben sem merült fel az a gondolat, hogy az EJEE 11. cikkét a fentieknek megfelelöen kellene értelmezni, ám mégis azt mondhatjuk, hogy ez az ítélet alapozta meg a sztrájkjog EJEB általi elismerését. Ebben az ügyben mondta ki ugyanis, hogy az EJEE által biztosított jogok - és így az egyesülési szabadság és a koalíciós szabadság - értelmezése során nem az EJEE az egyetlen referencia az EJEB számára, ${ }^{43}$ hanem figyelemmel kell lennie a nemzetközi jog egyéb forrásaira, az ezeket értelmező kompetens szervek megállapításaira, valamint az európai államok gyakorlatára. ${ }^{44}$ Így adott esetben a nemzetközi jog olyan releváns szabályai is alkalmazásra kerülhetnek, mint például az Európai Szo-

37 Schmidt and Dahlström ügyben hozott itélet, 36. pont; a Wilson, National Union of Journalists and Others kontra Egyesült Királyság ügy, 2002. július 2-i ítélet (ügyszám: 30668/96, 30671/96, 30678/96), 45. pont.

38 Swedish Engine Drivers' Union ügyben hozott ítélet, 40. pont.

39 Ezen más eszközök pontos körét nem határozta meg a bíróság. A Swedish Engine Drivers' Union ügyben hozott ítélet, 36. pont.

40 Davies (2009): i. m., 178.

41 Wilson, National Union of Journalists and Others ügyben hozott ítélet, 46. pont.

42 Davies (2009): i. m., 177.

43 Demir and Baykara ügyben hozott ítélet, 67. pont.

${ }^{44}$ Demir and Baykara ügyben hozott ítélet, 85. pont. 
ciális Charta és a Módosított Európai Szociális Charta, vagy akár az ILO vonatkozó egyezményei, továbbá az Európa Tanács szerveinek kötelező erővel nem bíró normái, ajánlásai, jelentései. ${ }^{45}$ Mivel az EJEE egyfajta „élő” jog, az EJEB-nek figyelemmel kell lennie a nemzeti és nemzetközi jog változásaira is, illetve mindig az aktuális körülmények és nemzetközi jogi helyzet fényében kell értelmeznie az EJEE-ben biztosított jogokat és szabadságokat. ${ }^{46}$ Az EJEB-nek szem előtt kell tartania, hogy az EJEE-ben biztosított jogokat úgy kell értelmeznie, hogy azok a gyakorlatban hatékonyan tudjanak érvényesülni, és ne üresedjenek ki. ${ }^{47}$

A Demir and Baykara ügyig az EJEB a koalíciós szabadságnak kizárólag a következő lényeges elemeit (tulajdonképpen részjogait) ismerte el az EJEE 11. cikke alapján védendő alapjognak: a szakszervezet-alakítás joga, a szakszervezethez történő csatlakozás joga, a closed shop megállapodások tilalma, valamint a szakszervezetek munkáltató általi meghallgatásának joga. ${ }^{48} \mathrm{Ez}$ a lista az aktuális ügyben a kollektív alkuhoz való joggal bővült tovább. Kiemelten fontos az EJEB azon megállapítása, amely szerint az EJEE 11. cikke által védett szakszervezeti jogok felsorolása nem taxatív, a jövőben bármikor bővíthető a nemzeti és nemzetközi (munka)jogban időközben bekövetkező változásokra tekintettel. ${ }^{49}$

Az EJEB továbbá azt is kiemelte, hogy az EJEE értelmezése során felhasznált jogforrások között nem tesz különbséget aszerint, hogy az adott ügyben félként szereplő részes állam ratifikálta-e azokat. ${ }^{50}$ Ez volt az egyik kritikus pontja ennek az ítéletnek, hiszen ez alapján az EJEB lényegében olyan jogok tiszteletben tartására - és így olyan nemzetközi egyezmények megtartására - kötelezheti a részes államokat, amelyeket nem mindegyikük írt alá és ültetett át a belső jogába. Az EJEB szerint ahhoz ugyanis, hogy valamely egyezményt vagy a nemzetközi jog egyéb forrását felhasználhassa az EJEB az alapvető jogok interpretálása során, elegendő, hogy azt az EJEE részes államainak többsége ratifikálja, még ha az adott ügyben félként szereplö állam nem is tette ezt meg. ${ }^{51}$

A Demir and Baykara ügyben az EJEB lényegében elökészítette a sztrájkjog későbbi elismerését, amelyre 2009-ben, az Enerji Yapi-Yol Sen ügyben került sor. Ebben az ítéletben az EJEB átvette a korábbi kisebbségi álláspontot, és kimondta, hogy a szakszervezetnek az EJEE által védelemben részesített érdekvédelmi tevékenysége elválaszthatatlanul összekapcsolódik a sztrájkhoz való joggal. Megállapította továbbá, hogy a sztrájkjog a kollektív alkuhoz való jog biztosításának hatékony eszköze, biztosítja ezen alapjog gyakorlását, és ebből kifolyólag a 11. cikk (1) bekezdése a sztrájkhoz való jogot ugyanúgy védelemben részesíti, mint az EJEE-ben explicite említett többi alapjogot. ${ }^{52}$ Tehát nem kérdés, hogy a 11. cikk védelemben

45 Például a Velencei Bizottság által készített jelentéseket, anyagokat is felhasználhatja a Bíróság. Demir and Baykara ügyben hozott ítélet, 75. pont.

46 Demir and Baykara ügyben hozott ítélet, 68. pont.

47 Demir and Baykara ügyben hozott ítélet, 66. pont.

48 Demir and Baykara ügyben hozott ítélet, 145. pont.

49 Demir and Baykara ügyben hozott itélet, 146. pont.

50 Demir and Baykara ügyben hozott ítélet, 77 . pont.

Demir and Baykara ügyben hozott ítélet, 86. pont.

52 Enerji Yapi-Yol Sen kontra Törökország ügy, 2009. április 21-i ítélet (ügyszám: 68959/01), 24. pont. 
részesíti a sztrájkhoz való jogot. Mivel azonban a sztrájkjog nem abszolút, meg kell határozni, hogy milyen keretek között gyakorolható, továbbá hogy milyen esetekben és terjedelemben korlátozható. ${ }^{53}$ Bár az EJEB nem tartotta korábban a sztrájkot az egyesülési szabadság biztosításához elengedhetetlennek, a Demir and Baykara ügyben lefektetett értelmezési módszert használva végül átvette az ILO értelmezését, ${ }^{54}$ amely szerint a sztrájkjog a munkavállalókat megillető egyesülési szabadság lényegi velejárója. ${ }^{55}$ Elemi érdek, hogy a szakszervezetek érdekvédelmi tevékenysége védelmet élvezzen, tekintet nélkül arra, hogy azt milyen formában valósítják meg, ${ }^{56}$ hiszen csak így biztosítható a munkavállalók számára védelem a munkáltatókkal szemben. Az EJEB ezen álláspontjának kialakítása során az ILO gyakorlata mellett figyelemmel volt az Európai Szociális Charta sztrájkjoggal kapcsolatos rendelkezésére is, amelyet így lényegében olyan államok tekintetében is alkalmazott, illetve alkalmaz, amelyek a Charta vonatkozó cikkét nem ratifikálták. ${ }^{57}$

Végül meg kell említeni, hogy önmagában az a tény, hogy a sztrájk nem hozta meg a kívánt eredményt, nem jelenti, hogy az EJEE 11. cikke által védett jog illuzórikus, ${ }^{58}$ mivel a sztrájkhoz való jog (valamint a kollektív alkuhoz való jog) biztosítása nem jelenti azt, hogy a munkáltató köteles lenne kollektív szerződést kötni a szakszervezettel vagy a munkavállalókkal. Az EJEE kizárólag azt követeli meg, hogy a szakszervezeteknek meglegyen a lehetösége a 11. cikkel összhangban arra, hogy törekedjenek tagjaik érdekeinek védelmére, ${ }^{59}$ amelynek legfontosabb eszköze a sztrájk. A munkáltató azonban nem kötelezhető kollektív szerződés megkötésére, mivel az EJEE ilyen kötelezettséget nem tartalmaz, és nem is tartalmazhat a releváns nemzetközi és nemzeti gyakorlatokra tekintettel.

Összességében elmondható, hogy ma már azt vallja az EJEB, hogy az EJEE 11. cikke egyértelmüen védelemben részesiti a sztrájkhoz való jogot a kollektív alkuhoz való jog részeként. ${ }^{60} \mathrm{~A}$ sztrájkhoz való jog ily módon az EJEB értelmezése szerint alapjog, amely második generációs jellege ellenére az EJEE-ben foglalt első generációs jogokkal azonos védelmet élvez. Ez a védelem azonban nem jelenti azt, hogy semmilyen körülmények között sem korlátozható a sztrájkhoz való jog.

53 Enerji Yapi-Yol Sen ügyben hozott ítélet, 32. pont.

54 Az ILO 87. számú egyezménye, ami a munkavállalók egyesülési és szervezkedési szabadságáról szól, szintén nem mondja ki explicite a sztrájkhoz való jogot, ám az ILO illetékes szervei az egyezmény értelmezése során kiolvasták e jogot annak rendelkezéseiből. Relevanciával bír továbbá e témakör szempontjából a szervezkedési jog és a kollektív tárgyalási jog elveinek alkalmazásáról szóló 98. sz. egyezmény, valamint a közszolgálatban foglalkoztatottak szervezkedési szabadságának védelméről és a foglalkoztatási feltételeik megállapításával kapcsolatos eljárásokról szóló 151. sz. egyezmény, amelyek szintén megjelennek az ILO gyakorlatában a sztrájkkal összefüggésben.

55 Enerji Yapi-Yol Sen ügyben hozott ítélet, 24. pont.

56 Grabenwarter, Christoph: European Convention on Human Rights - Commentary. C. H. Beck, Hart, Nomos, Helbing Lichtenhahn Verlag, 2014, 303.

57 Demir and Baykara ügyben hozott ítélet, 153-154. pont; Enerji Yapi-Yol Sen ügyben hozott ítélet, 31-32. pont.

58 Bár a Bíróság ezt a megállapítást a szolidaritási sztrájk kapcsán emelte ki, alkalmazható az elsődleges sztrájk kapcsán is. National Union of Rail, Maritime and Trasport Workers kontra Egyesült Királyság ügy, 2014. április 8-i ítélet (ügyszám: 31045/10), 85. pont.

59 National Union of Rail, Maritime and Trasport Workers ügyben hozott ítélet, 85. pont.

60 Veniamin Tymoshenko and Others kontra Ukrajna ügy, 2014. október 2-i ítélet (ügyszám: 48408/12), 78. pont. 


\subsection{A sztrájkhoz való jog korlátozása az EJEB gyakorlatában}

A sztrájkjog nem abszolút, ${ }^{61}$ ezért eleve csak korlátozásokkal érvényesül. ${ }^{62}$ Azonban az EJEB a 11. cikk kapcsán megállapította, hogy a koalíciós szabadság lényeges tartalma nem korlátozható, ${ }^{63}$ amit álláspontunk szerint alkalmazni kell a 11. cikk által védett, az egyesülési szabadságból és koalíciós szabadságból levezetett sztrájkjogra is. Az EJEE 11. cikke kapcsán korlátozásnak kell tekinteni a sztrájk tilalmát, ${ }^{64}$ valamint a sztrájkjog gyakorlásához szükséges engedély megtagadását. Ide kell sorolni továbbá azokat a szankciókat és fegyelmi büntetéseket is, amelyek a sztrájkhoz való jog jogszerü gyakorlása esetén kerülnek alkalmazásra (például felmondás) ${ }^{65}$ Ezen büntető jellegü intézkedések akkor is az EJEE-be ütköző módon korlátozhatják a sztrájkjogot, ha nem különösebben súlyosak. Önmagában a büntetés kilátásba helyezése alkalmas lehet ugyanis arra, hogy a szakszervezetet és tagjait eltántorítsa a sztrájkban való részvételtől, és így a sztrájkjog korlátozását eredményezheti, ${ }^{66}$ amit igazolni kell az EJEE és az EJEB által felállított szempontrendszer mentén.

Nincs lehetőség a sztrájk generális tilalmára, mivel az gátolná a szakszervezetet érdekvédelmi tevékenységének ellátásában. ${ }^{67}$ Bizonyos személyi kör, mint például a közszolgálati jogviszony keretében foglalkoztatottak meghatározott csoportjai tekintetében ugyan van lehetőség a sztrájk tiltására, ${ }^{68}$ ám egy ilyen tilalom nem érintheti a közszférában, valamint az állami tulajdonú kereskedelmi és ipari vállalatoknál dolgozók teljes körét. ${ }^{69}$ Ezen túlmenően egy meghatározott személyi kör tekintetében pedig tulajdonképpen maga az EJEB mondja ki, hogy tilos a sztrájk. Az üzemi tanács például, amely a munkavállalók részvételi jogait gyakorolja a munkáltatói döntéshozatalban, lényegét tekintve egy neutrális szerv, amely pártatlanságát csak úgy tudja megőrizni, ha tagjai nem sztrájkolhatnak, de legalábbis nem üzemitanács-tagi minőségükben. Ez jellemzően oly módon oldható meg, hogy amennyiben az üzemi tanács valamelyik tagja mégis részt venne a sztrájkban, ${ }^{70}$ akkor annak a tagnak üzemi tanácsi tagsága a sztrájk idejére szünetel. Az EJEB esetjogából az olvasható ki, hogy az üzemi tanács nem tekinthető az EJEE 11. cikke szerinti (szak)szervezetnek, ${ }^{71}$ mivel nem felelnek meg többek között az EJEE és az EJEB gyakorlata által

61 Enerji Yapi-Yol Sen ügyben hozott ítélet, 32. pont.

62 Az Enerji Yapi-Yol Sen ügyben hozott ítélet, 32. pont; Schmidt and Dahlström ügyben hozott ítélet, 36. pont.

63 Demir and Baykara ügyben hozott ítélet, 144. pont.

64 UNISON kontra Egyesült Királyság ügy, 2002. január 10-i elfogadhatósági határozat (ügyszám: 53574/99).

65 Trofimchuk kontra Ukrajna ügy, 2010. október 28-i ítélet (ügyszám: 4241/03), 35. pont.

66 Saime Özcan kontra Törökország ügy, 2009. szeptember 15-i ítélet (ügyszám: 22943/04), 22. pont; Enerji Yapi-Yol Sen ügyben hozott ítélet 32. pont.

67 Enerji Yapi-Yol Sen ügyben hozott ítélet, 32. pont.

68 Az EJEE 11. cikk (2) bekezdése értelmében a fegyveres erők, a rendőrség és az államigazgatás tagjainak sztrájkjoga kimondottan korlátozható.

69 Enerji Yapi-Yol Sen ügyben hozott ítélet, 32. pont; KAJTÁR: i. m., 69.

70 Ez nem egy hipotetikus eset, mivel szakszervezeti tagok és tisztségviselők jellemzően nagy arányban vannak jelen az üzemi tanácsokban.

71 Mümtaz Karakurt kontra Ausztria ügy, 1999. szeptember 14-i ítélet (ügyszám: 32441/96). 
támasztott önkéntesség követelményének. ${ }^{72}$ Ezért az üzemi tanácsot vagy annak tagját az EJEE 11. cikke szerinti védelem - és így a sztrájkhoz való jog - e minőségében nem, csak szakszervezeti tagként illeti meg.

Amennyiben a sztrájkjog korlátozására kerül sor, az akkor jogszerü és nem eredményezi az EJEE 11. cikkének sérelmét, amennyiben ez a korlátozás törvényben meghatározott, törvényes cél(oka)t szolgál, továbbá szükséges egy demokratikus társadalomban, ${ }^{73}$ valamint az elérni kívánt céllal arányos.

A korlátozás akkor „törvény által elöírt”, ha annak jogszabályi alapja van a belső jogban. ${ }^{74} \mathrm{Nem}$ feltétel, hogy törvényi szintü legyen az elöírás, alacsonyabb szintü jogszabályban is rögzíthető a korlátozás ${ }^{75}$ sőt akár bírói döntés is tartalmazhatja azt, mivel a bíróság a jogszabályok rendelkezéseinek értelmezése alapján hozza meg határozatát. Fontos továbbá, hogy a korlátozást előíró rendelkezések, illetve jogszabály a címzettek számára hozzáférhető legyen (például hivatalos lapban történő közzététel útján). ${ }^{76}$ Mindezeken túlmenően a korlátozó intézkedést mindig úgy kell megalkotni, hogy annak ismeretében, észszerủ körültekintés mellett az érintettek elöre láthassák a sztrájkkal kapcsolatos magatartásuk, akcióik következményeit. ${ }^{77} \mathrm{Nem}$ felel meg ezért az elöreláthatóság és világosság követelményének a sztrájkjog korlátozása, amennyiben két különbözö, ám azonos szintű jogszabály is tartalmazza, ${ }^{78}$ mely esetekben tilos a sztrájk, ám e tilalmazott esetek köre egymástól némileg eltér egymástól, ${ }^{79}$ mivel ezzel bizonytalanná válik a munkavállalók és a szakszervezetek számára, hogy mikor indíthatnak sztrájkot és mikor nem, amelyböl fakadóan nem is láthatják elöre az általuk kezdeményezett akciók (munkajogi) következményeit.

Az EJEE-ben foglalt jog korlátozásával elérendő törvényes célok körét maga az EJEE határozza meg, taxatív jelleggel: a nemzetbiztonság, a területi sértetlenség, a közbiztonság, a zavargás vagy bűnözés megelőzése, a közegészség vagy az erkölcsök védelme, mások jó hírneve vagy jogai védelme, a bizalmas értesülés közlésének megakadályozása, vagy a bíróságok tekintélyének és pártatlanságának fenntartása érdekében van mód a sztrájkhoz való jogot korlátozó intézkedést megalkotni. ${ }^{80}$ Mások jogainak védelmére hivatkozva korlátozható a sztrájkjog, amennyiben a tervezett munkabeszüntetés például más szakszervezetek ${ }^{81}$ vagy a közösség

72 Dorssemont, Filip-LöRCher, Klaus-Schömann, Isabelle: The European Convention on Human Rights and the Employment Relation. Bloomsbury Publishing, 2013, 350.

73 EJEE, 11. cikk (2) bekezdés.

74 Enerii Yapi-Yol Sen ügyben hozott ítélet, 26. pont.

75 Enerii Yapi-Yol Sen ügyben hozott ítélet, 26. pont.

76 Veniamin Tymoshenko and Others ügyben hozott ítélet, 80. pont.

77 Veniamin Tymoshenko and Others ügyben hozott ítélet, 80. pont.

78 A hivatkozott esetben a kollektív munkaügyi vitákat rendező törvény, valamint a szállításról és fuvarozásról szóló törvény is taxatíve határozta meg azokat az eseteket, amikor a munkavállalók számára tilos a sztrájk. Csakhogy a világosság követelményének ellentmondott, hogy a két jogszabály által felsorolt esetkörök nem teljesen fedték egymást, s így nem volt világos az érintettek számára, hogy mely szabálynak kell megfelelniük. Veniamin Tymoshenko and Others ügyben hozott ítélet, 84. pont.

79 Veniamin Tymoshenko and Others ügyben hozott ítélet, 81-84. pontok.

80 EJEE 11. cikk (2) bekezdés.

81 Hrvatski Liječnički Sindikat kontra Horvátország ügy, 2014. november 27-i ítélet (ügyszám: 36701/09), 57. pont. 
tagjainak ${ }^{82}$ jogait veszélyezteti. De a munkáltató jogai is védendő érdeket képviselnek, ${ }^{83}$ amennyiben a sztrájk miatt nem tudná feladatát hatékonyan ellátni, valamint a harmadik személyekkel kötött szerződéseiben foglaltakat teljesíteni. ${ }^{84}$ Mindez azonban nem jelenti, hogy a munkáltató gazdasági érdekei fontosabbak a munkavállalók alapjogainál, ${ }^{85}$ kizárólag a munkáltató jogai, nem pedig érdekei élveznek védelmet. Előfordulhat, hogy a munkavállalót azért éri valamilyen büntető jellegű intézkedés a munkáltató részéröl (például az megszüntette a jogviszonyát), mert oly módon szegte meg munkavégzési és rendelkezésre állási kötelezettségét, hogy eközben nem teljesítette a jogszerü sztrájk gyakorlásának jogszabályban lefektetett követelményeit (és egyébként a munkáltató sem akadályozta a sztrájkjog jogszerü gyakorlásához szükséges eljárás lefolytatásában). Például nem értesíti előzetesen a munkáltatói jogkör gyakorlóját arról, hogy részt fog venni a sztrájkban, s ennek következtében kerül alkalmazásra valamilyen szankció. llyenkor ez az adott munkavállaló tekintetében a sztrájkjog korlátozásának tekinthető, amely azonban összhangban áll az EJEE 11. cikk (2) bekezdésével, ${ }^{86}$ ugyanis törvényes célt szolgál, mégpedig a munkáltató jogainak védelmét azon munkavállalóval szemben, aki nem a jogszabályi rendelkezések megtartása mellett vett részt a sztrájkban. ${ }^{87}$

Abban a tekintetben, hogy a korlátozás szükséges-e egy demokratikus társadalomban, azaz sürgetö társadalmi szükségletet elégítene-e ki, a sztrájkjog gyakorlásának lehetséges gazdasági és társadalmi következményeit kell értékelni.

Amennyiben egy korlátozás a törvény által elöírt, törvényes célt szolgál, és egy demokratikus társadalomban szükséges, akkor is meg kell vizsgálni, hogy az elérni kívánt céllal arányos-e. Amennyiben ugyanis a sztrájkhoz való jog korlátozása aránytalannak bizonyul, akkor az az EJEE 11. cikkének sérelmét fogja eredményezni. Például egy olyan rendelkezés, amely több évre előre kizárja a sztrájk lehetőségét, egyértelmüen aránytalan. ${ }^{88}$ Amennyiben azonban a korlátozás nem a szakszervezet tevékenységének lényegét érinti, hanem annak csupán egy marginális elemét, akkor arra nézve az arányossági szabályokat kevésbé szigorúan kell értelmezni: a másodlagos sztrájk esetében, annak jellegéből fakadóan valószínü, hogy az azt tiltó vagy korlátozó jogszabály megfelel az arányosság követelményének ${ }^{89} \mathrm{Nem}$ tekinthető azonban arányosnak, amennyiben az állami szolgálatot ellátók számára generálisan tilos, hogy egy egynapos nemzeti szintủ sztrájkban részt vehessenek. ${ }^{90}$

82 UNISON-ügyben hozott elfogadhatósági határozat.

83 UNISON-ügyben hozott elfogadhatósági határozat.

84 UNISON-ügyben hozott elfogadhatósági határozat.

85 National Union of Rail, Maritime and Transport Workers ügyben hozott ítélet, 80. pont.

86 Trofimchuk-ügyben hozott ítélet, 44. pont.

87 Trofimchuk-ügyben hozott itélet, 45. pont.

88 Hrvatski Liječnički Sindikat ügyben hozott ítélet, 59. pont.

89 National Union of Rail, Maritime and Transport Workers ügyben hozott ítélet, 87. pont.

90 Enerji Yapi-Yol Sen ügyben hozott ítélet, 32. pont; Schmidt and Dahlström ügyben hozott ítélet, 33. pont; Swedish Engine Drivers' Union ügyben hozott ítélet, 37. pont. 


\subsection{A szolidaritási sztrájk az Emberi Jogok Európai Bíróságának gyakorlatában}

A sztrájkjog célja a munkavállalók gazdasági és szociális érdekeinek előmozdítása, ezért a tisztán politikai célokat szolgáló sztrájk jogellenes. Kérdés azonban, hogy mi a helyzet a már meglévő sztrájkhoz való csatlakozás tipikus esetével, az ún. szolidaritási sztrájkkal vagy szimpátiasztrájkkal, ${ }^{91}$ amikor a munkavállalók lényegében nem saját gazdasági és szociális érdekeikért szállnak harcba, hanem egy másik sztrájkban részt vevő munkavállalókkal lényegében szolidaritást vállalnak, a szimpátiájukat fejezik ki irányukban, ily módon támogatják azok követeléseit. Jellemzően az ilyen, szimpátiát kifejező sztrájk nem jogellenes, amennyiben a munkavállalói gazdasági és szociális érdek közvetlenül vagy akár közvetve kimutatható, ${ }^{92}$ ám szigorú feltételekhez kötött, mivel egy támogató jellegủ sztrájk során olyan munkáltatónál is keletkez(het)nek károk, akinek nem áll módjában a sztrájkköveteléseket teljesíteni.

Az a kérdés, hogy az EJEE 11. cikke a sztrájkhoz való jogon belül védelmet nyújt-e a másodlagos sztrájknak (secondary strike), a 2014-es National Union of Rail, Maritime and Transport Workers ügyben merült fel. Az EJEB hivatkozta ${ }^{93}$ a Demir and Baykara ügyben tett azon megállapítását, hogy az EJEE értelmezése során az EJEB figyelembe veheti, és figyelembe is kell vennie a nemzetközi jog egyéb egyezményeit, a nemzetközi szervezetek (jelen esetben például az ILO) jogértelmezését, valamint a tagállamok gyakorlatát ${ }^{94} \mathrm{Ez}$ igaz az EJEE 11. cikkének értelmezésére is, amely során a Bíróság köteles figyelembe venni a sztrájkjoggal kapcsolatos nemzetközi egyezmények és szervezetek releváns megállapításait, így pedig az EJEB sztrájkértelmezése nem lehet szükebb a nemzetközi jogénál ${ }^{95}$ - márpedig az alapján kijelenthető, hogy a szolidaritási sztrájk szintén a szakszervezetek jogszerű akciójának tekinthető, érdekvédelmi tevékenységükhöz kapcsolódó akció. Ehhez azonban hozzátartozik, hogy a szolidaritási sztrájk nem tekinthető a koalíciós szabadság lényeges aspektusának, inkább a szakszervezet érdekvédelmi tevékenységének egyfajta tartozékaként funkcionál. ${ }^{96}$ Ezért a szolidaritási sztrájkot az EJEE 11. cikk (1) bekezdése által védett szakszervezeti akciónak kell tekintetni, ${ }^{77}$ bár ez esetben a jog korlátozása esetén szélesebb mozgástér áll az államok rendelkezésére, mivel a szolidaritási sztrájk nem a szakszervezeti érdekvédelem lényegét érintő akció. Ennek megfelelően másodlagos sztrájk kapcsán már-már vélelmezhető, hogy az azt korlátozó vagy tiltó rendelkezés arányos, mivel a korlátozás, illetve a tiltás nem a koalíciós szabadság, illetve a sztrájkjog lényegét érinti. ${ }^{98}$

91 KIss György: Munkajog. Osiris Kiadó, Budapest, 2000, 456.

92 Kiss (2000): i. m., 458.

93 National Union of Rail, Maritime and Transport Workers ügyben hozott ítélet, 76 pont.

94 Demir and Baykara ügyben hozott ítélet, 85. pont.

95 National Union of Rail, Maritime and Transport Workers ügyben hozott ítélet, 76 pont.

96 National Union of Rail, Maritime and Transport Workers ügyben hozott ítélet, 77. pont.

97 National Union of Rail, Maritime and Transport Workers ügyben hozott ítélet, 77. pont.

98 National Union of Rail, Maritime and Transport Workers ügyben hozott ítélet, 87-88. pontok. 


\section{Az EJEB sztrájkjoggal kapcsolatos gyakorlatának hatása az uniós jogra}

A 2009-ben hatályba lépett Lisszaboni Szerződés értelmében az EU számára megnyilt a lehetőség arra, hogy csatlakozzon az Emberi Jogok Európai Egyezményéhez, ${ }^{99}$ illetve már meg is tette az első lépéseket a csatlakozás irányában. Ebből következik, hogy az alapvető jogok, ahogyan azokat az EJEE biztosítja, továbbá ahogyan azok a tagállamok közös alkotmányos hagyományaiból következnek, az uniós jogrend részét képezik, mint annak általános elvei. ${ }^{100}$ Ezen túlmenően pedig az Európai Unió Alapjogi Chartája kimondja, hogy amennyiben a Charta olyan jogokat tartalmaz, amelyeket az EJEE is biztosít, akkor a Chartában szereplő jogok tartalmát és terjedelmét azonosnak kell tekinteni az EJEE-ben lévő jogok tartalmával és terjedelmével. ${ }^{101}$ Ezzel lényegében az EJEE-ben foglalt jogok betartatása, valamint az EJEB esetjoga - elméletben - kötelezővé vált az Európai Unió Bírósága (EUB) számára is, ezért a sztrájkhoz való jog kapcsán (is) érdemes az EJEB esetjogára figyelemmel lenni.

A sztrájkjog szabályozása a munkajog egyéb területeivel ellentétben kizárólag tagállami hatáskörben maradt, még a minimum standard követelményeket sem határozhatja meg az EU. ${ }^{102}$ Ennek nem mond ellent, hogy az Alapjogi Charta 28. cikke értelmében biztositani kell a kollektív fellépéshez való jogot, amely magában foglalja a sztrájkjogot is. Ez ugyanis nem azt jelenti, hogy a Chartára történő hivatkozással az EU a sztrájkot jogalkotás útján bármilyen módon szabályozhatná. ${ }^{103}$ Éppen ellenkezőleg, a sztrájkjog 28. cikkbe történő beiktatásának csupán az a célja, hogy elejét vegye minden olyan uniós jogalkotási kísérletnek, amely a sztrájkhoz való jog elismerésével menne szembe. ${ }^{104}$ Mivel azonban az uniós jog alkalmazása során az EU intézményeinek tekintettel kell lenniük a Charta rendelkezéseire, így az EUB az uniós jog értelmezése során a sztrájkjog tartalmát, terjedelmét és korlátozhatóságát is köteles vizsgálata tárgyává tenni egy-egy konkrét esetben, ha valamely közösségi szabály interpretálása során erre szükség van.

Éppen ez történt a 2007-es Viking és Laval ügyekben, amelyekben az EUB a munkavállalók kollektív fellépéshez való jogát a közösségi jog általános alapelveként deklarálta, és azt is kijelentette, hogy bár fő szabály szerint a tagállamok hatáskörébe tartozik a sztrájkjog szabályozása, ezt az uniós jog tiszteletben tartásával kell tenniük. ${ }^{105}$ Mindkét ügy egy alapjog és egy alapszabadság kollíziójának feloldását kísérli meg: egyik oldalon a kollektív fellépéshez való jog áll - amelybe az Alapjogi Charta szerint

99 Európai Unióról Szóló Szerződés, 6. cikk (2) bekezdés.

100 Európai Unióról Szóló Szerződés, 6. cikk (3) bekezdés.

101 Alapjogi Charta, 52. cikk (3) bekezdés.

102 Európai Unió Működéséről Szóló Szerződés, 153. cikk (5) bekezdés.

103 Alapjogi Charta, 51. cikk (2) bekezdés.

104 PIRIs, Jean-Claude: The Lisbon Treaty. A Legal and Political Analysis. Cambridge University Press, Cambridge, 2010, 157.

105 C-435/05. sz., International Transport Workers' Federation és Finnish Seamen's Union kontra Viking Line ABP és OÜ Viking Line Eesti ügyben hozott ítélet (ECLI:EU:C:2007:772), 40. és 44. pont (a továbbiakban: Viking-ügy). C-341/05. sz., Laval un Partneri Ltd kontra Svenska Byggnadsarbetareförbundet, Svenska Byggnadsarbetareförbundets avdelning 1, Byggettan és Svenska Elektrikerförbundet ügyben hozott ítélet (ECLI:EU:C:2007:809), 87. és 91. pont (a továbbiakban: Laval-ügy). 
beleértendő a sztrájkjog is -, a másik oldalon pedig az uniós jog által biztosított letelepedés szabadsága és szolgáltatásnyújtás szabadsága. Az eldöntendő kérdés az volt, hogy melyik korlátozható a másik érvényesülése érdekében, és milyen feltételek teljesülése esetén.

Ahogy az EJEE, úgy az Alapjogi Charta is lehetöséget ad a sztrájkjog korlátozására. ${ }^{106}$ Ennek azonban feltétele, hogy csak a törvény által meghatározottan, az EU által elismert általános érdekü célkitüzés vagy mások jogainak és szabadságának védelme érdekében és a jog lényeges tartalmának tiszteletben tartásával kerülhet rá sor, amennyiben az intézkedés az elérni kívánt céllal arányos, valamint annak eléréséhez szükséges (elengedhetetlen). Tulajdonképpen az elvégzendő teszt elviekben hasonlít arra, amit az EJEB is alkalmaz. Csakhogy az EJEB és az EUB között alapvető felfogásbeli különbség van a sztrájkjog korlátozhatóságára irányuló vizsgálat kiindulópontja tekintetében.

Az EU egy olyan sajátos, sui generis jogrendszerrel bír, amely a sztrájkhoz való joggal kapcsolatos jogértelmezést is speciális problémákkal állítja szembe, amelyek mind a Viking-, mind a Laval-esetben meg is mutatkoznak. A két ügyben ugyanis „...nem egyszerüen a gazdasági és szociális (vagy annak vélt) alapjogok kollíziója okoz problémát, hanem e jogok eltérő szintje". ${ }^{107}$ Az EUB elé került esetekben az alapszabadságok egyike ${ }^{108}$ - ami az EU egyik meghatározó pillére - ütközik a kollektív fellépés jogával, amelynek alapjogi jellegét ${ }^{109}$ maga az EUB is elismeri. Márpedig az EUB az alapvető jogok érvényesítése, illetve korlátozása során - az EJEBbel ellentétben - köteles figyelembe venni azokat az alapszabadságokat, amelyek az EU alappillérei közé tartoznak. ${ }^{110}$ Az EUB szerint a kollektív fellépés joga - és így a sztrájkjog - korlátozható, azonban „,...az alapvető jogok védelme olyan jogos érdeket képez, amely fö szabály szerint igazolhatja a közösségi jog által megállapított, sőt akár a Szerződésben biztositott valamely olyan alapvető szabadságból fakadó kötelezettségek korlátozását is, mint amilyen az áruk szabad mozgása". 111 A korábbi gyakorlat megmutatta, hogy amennyiben olyan alapjog ütközik valamely alapszabadsággal, amely a polgári és politikai jogok közé tartozik, akkor az adott esetben jogszerüen korlátozható az alapszabadság. ${ }^{112} \mathrm{~A}$ Viking-, valamint a Lavalesetből azonban az olvasható ki, hogy a hagyományosan második generációs jogok közé sorolt sztrájkjog esetében erre gyakorlatilag nincs lehetőség, mivel egy olyan

106 Az Európai Unió Alapjogi Chartája, 52. cikk (1) bekezdés.

107 Kıss György: A,szabad mozgás” közösségi jogi pillére versus a munkavállalók kollektív fellépésének alapjoga. Pécsi Munkajogi Közlemények, 2008/2, 76.

108 A Viking-ügyben a letelepedés szabadsága, míg a Laval-ügyben a szolgáltatásnyújtás szabadsága került kollízióba a sztrájkjoggal.

109 C-435/05. sz., Viking-ügyben hozott ítélet, 33. pont; C-341/05. sz., Laval-ügyben hozott itélet, 91. pont.

110 Veldman Albertine: The Protection of the Fundamental Right to Strike within the Context of the European Internal Market: Implications of the Forthcoming Accession of the EU to the ECHR. Utrecht Law Review, 2013/1, 104.

111 C-438/05. sz., Viking-ügyben hozott ítélet, 45. pont; C-341/05. sz., Laval-ügyben hozott ítélet, 93. pont.

112 Például a C-112/00. sz., Eugen Schmidberger, Internationale Transporte und Planzüge kontra Republik Österreich ügyben hozott ítélet (ECLI:EU:C:2003:333). Lásd még VELYVYTE, Vilija: The Right to Strike in the European Union after Accession to the European Convention on Human Rights: Identifying Conflict and Achieving Coherence. Human Rights Law Review, 2015/1, 88. 
szigorú arányossági tesztet alkalmazott az EUB, amelynek követelményeit a szakszervezetek oldaláról már-már lehetetlen teljesíteni, s így eltántorítja őket a sztrájk kezdeményezésétől. Az EUB megállapításai szerint ugyanis amennyiben egy alapjog és egy alapszabadság ellentétbe kerül egymással, akkor egy esetleges kollektív fellépés arányosságát minden egyes esetben igazolni kell. Vagyis a sztrájkjog (mint alapjog) önmagában az alapszabadság korlátozását nem igazolhatja mindig szükség van magának a sztrájknak az igazolására, amelynek során annak arányosságát is bizonyítani kell. ${ }^{113}$ Ezzel az EUB lényegében amellett foglalt állást, hogy az alapszabadságok és a második generációs alapjogok, illetve az EU gazdasági és szociális értékei között hierarchia van, az utóbbiak rovására. ${ }^{114}$

A két bíróság felfogása a sztrájkhoz való joggal, illetve annak korlátozhatóságával kapcsolatosan tehát alapjaiban tér el, annak ellenére, hogy mind az EJEB, mind az EUB elismeri a sztrájkjog alapjogi jellegét. Az EJEB abból indul ki, hogy e jog bármiféle korlátozása az EJEE-be ütközik, kivéve, ha e korlátozás az EJEE 11. cikk (2) bekezdésében foglalt cél érdekében történik, és az arányosság követelményének is megfelel. Ezzel szemben az EUB kiindulási pontja teljesen eltérő, s így lényegében éppen az EJEB-bel ellentétes megállapításra jut: a sztrájk az, ami korlátozza az EU egyik alapvető elvének számító alapszabadságot, és nem fordítva. Márpedig a sztrájk csak akkor korlátozhatja az alapszabadságot, ha a szakszervezet bizonyítja, hogy a korlátozás (sztrájk) a Szerződéssel összeegyeztethető legitim célt szolgál, közérdeken alapuló kényszerítő indokok igazolják, továbbá az elérni kívánt cél megvalósítására alkalmas, és nem lépi túl az ahhoz szükséges mértéket (arányos). ${ }^{115} \mathrm{Az}$ EUB tehát nem részesíti védelemben a sztrájkjogot per se, hanem kizárólag azt a sztrájkot, amely a munkahelyek létére vagy a munkakörülményekre nézve komoly „fenyegetéseket” (például szociális dömping) ${ }^{116}$ igyekszik elhárítani, és erre alkalmas is. ${ }^{117}$ Ezért az alapvetően gazdasági célokat szolgáló alapszabadságok lényegében az alapjogok fölé emelkedtek a Viking- és a Laval-ügyben is, ${ }^{118}$ annak ellenére, hogy mindkét esetben hangsúlyozta az EUB azt a tényt, hogy mivel az EU-nak nemcsak gazdasági, hanem szociális célja is van, ezért a személyek, a szolgáltatások és a tőke szabad mozgására vonatkozó rendelkezéseiből származó jogokat egyensúlyba kell hozni a szociálpolitika célkitüzéseivel. ${ }^{119}$

Az ítéletekből az olvasható ki, hogy az Európai Unió Müködéséről Szóló Szerzödésnek az alapszabadságokról szóló cikkei horizontális közvetlen hatállyal bírnak,

113 Verica Trstenjak fötanácsnok indítványa a C-271/08. sz., Európai Bizottság kontra Németországi Szövetségi Köztársaság ügyben (ECLI:EU:C:2010:183), 183-184. pont; VeLYVYTE: i. m., 88.

114 VeLYVYTE: i. m., 74. és 84.

115 C-341/05. sz., Laval-ügyben hozott itélet, 101. pont.

116 A szociális dömpingnek nincs általánosan elfogadott definíciója. Az Európai Bizottság értelmezése szerint a szociális dömping azt jelenti, hogy más állam szolgáltatója az ottani kevésbé szigorú munkajogi szabályok miatt a helyi szolgáltatónál olcsóbban tudja nyújtani szolgáltatásait. http://ec.europa.eu/social/main. jsp?catld=471 (2016. 01. 05.).

117 Veldman: i. m., 109.

118 BARnARD, Catherine: EU Employment Law. Fourth Edition. Oxford University Press, Oxford, 2013, 722.

119 llyen célkitüzés többek között az élet- és munkakörülmények javítása, a megfelelö szociális védelem, valamint a szociális partnerek közötti párbeszéd biztosítása. C-341/05. sz., Laval-ügyben hozott ítélet, 105. pont. 
ezért a szakszervezet feladata igazolni az érintett alapszabadság korlátozását. ${ }^{120}$ Ráadásul az EUB jelentősen leszűkítette a szakszervezetek mozgásterét mind a sztrájk igazolására szolgáló célok, mind az arányossági követelmények kapcsán. ${ }^{121}$ Amennyiben a szakszervezet által kezdeményezett sztrájk végül nem felel meg ezeknek a rendkívül szigorú, és nem minden tekintetben világos kritériumoknak, a szakszervezetek olyan összegü kár megtérítésére kötelezhetök, amely teljesen a „padlóra” küldheti őket anyagilag, s akár fizetésképtelenség miatti megszüntetésüket is eredményezheti. Mindezek a körülmények együttesen alkalmasak arra, hogy visszatartsák a szakszervezeteket a sztrájk kezdeményezésétől, hiszen lényegében az ő feladatukká tette az EUB azt is, hogy tagjaik érdekein túlmenően mérlegeljék az alapszabadságok adta lehetőségeket kihasználó vállalkozás révén olcsóbb szolgáltatáshoz jutó közösség, vagyis harmadik személyek érdekeit, anélkül, hogy hivatkozni tudnának mindazokra a célokra az adott alapszabadság korlátozásakor, amelyekre az államnak viszont lehetősége van hivatkozni ilyen esetben (például közbiztonság). ${ }^{122}$

Végső soron tehát az EJEB gyakorlata alapján a sztrájkjog korlátozását szükséges igazolni, míg az EUB értelmezése szerint a sztrájk kezdeményezése szorul ilyen igazolásra. ${ }^{123}$ Amennyiben az EU valóban csatlakozik az Emberi Jogok Európai Egyezményéhez, az azt jelentené, hogy az EJEE és az EJEB által felállított védelmi szintnek kellene megfelelnie az alapjogok, például a sztrájkhoz való jog terén. Csakhogy jól láthatóan ezen alapvető jog kapcsán jelentősen eltér az EJEB és az EUB felfogása, ami akár közvetve magának a csatlakozásnak is a gátja lehet. Hiszen az EUB nyilvánvalóan nem szimpatizál majd azzal az eshetőséggel, ${ }^{124}$ hogy az EJEB az EU-n kívüli szervként felülírja az EUB korábbi gyakorlatát az alapvető jogok terén. Ezen túlmenően már most is problémát okozhat a két bíróság eltérő esetjoga a sztrájk vonatkozásában, mivel az EU tagállamai és az EJEE részes államai között jelentős átfedés van, és ily módon tulajdonképpen két, egymással ellentétes sztrájkértelmezést kellene a belső jogukba beépíteniük, ami nyilvánvalóan nem lehetséges. A kérdés tehát az, hogy melyik bíróság fog végül saját gyakorlatán változtatni annak érdekében, hogy az európai államok összhangba tudják hozni nemzetközi és uniós kötelezettségeiket. Természetesen lehetséges, hogy az EUB a Demir and Baykara és Enerji Yapi-Yol Sen ügyekben hozott EJEB ítéletek hatására módosít majd álláspontján, hiszen a sztrájkkal kapcsolatos megállapításait még bőven azelőtt tette, hogy az EJEB alapjogként ismerte volna el a sztrájkjogot, ezzel a polgári és politikai jogokkal azonos védelemben részesítve, ami nyilvánvalóan hatással lehet e jog EUB általi megítélésére is. Ezt látszik alátámasztani, hogy a korábbi bírósági gyakorlattól eltérve az Európai Bizottság kontra Németországi Szövetségi Köztársaság ügyhöz füzött indítványában Trstenjak fötanácsnok már amellett foglal állást, hogy

120 Davies, A. C. L.: One Step Forward, Two Steps Back? The Viking and Laval Cases in the ECJ. Industrial Law Journal, 2008/2, 126-127.

121 BARNARD: i. m., 207.

122 BARNARD: i. m., 204.

123 VELDMAN: i. m., 113.

124 Mindenesetre ez olvasható ki az EJEE-hez történő csatlakozás nyomán készített EUB-véleményből. A Bíróság 2/13. sz. véleménye (teljes ülés), 2014. december 18. (ECLI:EU:C:2014:2454). 
az alapszabadságok és az alapjogok egymással egyenrangúak, azonos szinten találhatók, ${ }^{125}$ így ütközésük esetén nem lehet kizárólag azt vizsgálni, hogy az alapjog jogszerüen korlátozza-e az alapszabadságot. Némileg talán az indítvány hatására ebben az ügyben mondta ki elöször az EUB azt, hogy megfelelő egyensúlyt (,fair balance") kell teremteni a munkavállalókat megillető alapjogok (így a sztrájkjog) és a belső piac alapját képező alapszabadságok között. ${ }^{126}$ Arra azonban még várni kell, hogy ez a sztrájkhoz való jog kapcsán is kimondásra kerüljön, de mindenképpen bizakodásra ad okot ez a változás.

\section{4. Összegzés}

Az EJEE tehát nem nevesíti a sztrájkhoz való jogot, mivel alapvetően első generációs jogok védelmére alkották meg, $s$ a klasszikus felosztásban a sztrájkjog a második generációs, vagyis a gazdasági, szociális és kulturális jogok közé tartozik. Az utóbbi néhány évtizedben azonban elindult egy folyamat, melynek révén egyes, a munka világára jellemző jogokat emberi jogi megközelítésből is vizsgálatuk tárgyává tettek a nemzetközi emberi jogi szervezetek és bíróságok. Ebbe a sorba illeszkedik az EJEB is, amely a 2000-es évek második felétöl kezdődően azt vallja, hogy a sztrájkjog kiolvasható az EJEE 11. cikke által védelemben részesített egyesülési szabadságból és koalíciós szabadságból. Ennek kapcsán az EJEB korábbi gyakorlatának tükrében tett megállapitásai a Demir and Baykara és az Enerji Yapi-Yol Sen ügyekben kifejezetten progresszívnek tekinthetök, és ma már alapvetően védelemben részesíti a szakszervezetek, illetve a munkavállalók sztrájkjogát annak érdekében, hogy a szakszervezet el tudja látni érdekvédelmi tevékenységét. Ezzel lényegében ahelyett, hogy kimondta volna az alapvető jogok univerzalitását, azt a szakirodalmi álláspontot tette magáévá az EJEB, amely azonos státuszúvá téve a gazdasági, szociális és kulturális jogokat a polgári és politikai jogokkal, és így inkább az első generációs jogokból vezeti le az egyes második generációs jogok alapjogi, emberi jogi jellegét. Ehhez azonban az EJEB változtatott korábbi értelmezési módszerén, mégpedig akként, hogy immár a különböző nemzetközi dokumentumok, így az ILO vonatkozó egyezményeit, valamint az Európai Szociális Charta szövegének értelmezését is alapul veszi. Ezzel azonban lényegében rákényszeríti a részes államokat arra, hogy legalábbis a sztrájkjog terén olyan nemzetközi emberi jogi és munkajogi egyezményeknek is megfeleljenek, amelyeket nem írtak alá és nem ratifikáltak. Hiába hangsúlyozza később is az EJEB, hogy hatáskör hiányában nem vizsgálhatja, hogy a sztrájkkal kapcsolatos nemzeti szabályozások megfelelnek-e az ILO és az Európai Szociális Charta követelményeinek, ${ }^{127}$ végső soron mégis azt teszi, amikor az EJEE értelmezése során az említett egyezmények szövegéböl és gyakorlatából indul ki. Ez pedig alááshatja az EJEE és az EJEB tekintélyét is a ré-

125 Verica Trstenjak főtanácsnok indítványa, 81. pont.

126 C-271/08. sz., Európai Bizottság kontra Németországi Szövetségi Köztársaság ügyben 2010. július 15-én hozott ítélet, 52. pont (ECLI:EU:C:2010:426).

127 National Union of Rail, Maritime and Transport Workers ügyben hozott ítélet, 106. pont. 
szes államok szemében, aminek súlyos következményei lehetnek, amennyiben az EJEB folytatja ezt a tendenciát.

Az EJEB sztrájkjoggal kapcsolatos gyakorlatának ezen túlmenően jelentős hatása lehet az EUB esetjogára is. Elméletben már most is figyelembe kellene venni az Alapjogi Chartában foglalt jogok értelmezése során az EJEE vonatkozó rendelkezéseit és az EJEB ítéleteit. Ez erősen ajánlott is lenne, különösen annak fényében, hogy az EU 2009 óta szabadon csatlakozhat az EJEE-hez, ami egyben kitüzött célja is, és az erre irányuló folyamat előkészítése már megindult. Amint az EU az EJEE részesévé válik, kötelező lesz rá nézve az EJEB gyakorlata is, így összhangba kell hoznia vele az EUB gyakorlatát. Azonban nemhogy erre irányuló lépések nem történtek, de a sztrájkjog tekintetében kifejezetten az EJEB esetjogával szembemenő gyakorlatot állított fel az EUB. Ezt az ellentmondásos helyzetet akarta feloldani az Európai Bizottság 2012-ben elkészített, de mára már visszavont javaslata, az ún. Monti II rendelet. Ennek értelmében nemcsak az alapszabadságokat kell tiszteletben tartani az alapjogok (köztük a sztrájkjog) gyakorlása során, hanem az alapjogokat is tiszteletben kell tartani az alapszabadságok gyakorlása során. Azaz egy alapjog és egy alapszabadság ütközése esetén kölcsönösen vizsgálni kell az arányosság követelményét. ${ }^{128} \mathrm{~A}$ rendelet megszületése hiányában azonban továbbra is az EUB-tól függ, hogy saját gyakorlatát az EJEB esetjogának megfelelően alakítja-e.

\section{Abstract}

The right to strike has been long recognized as an important labour right in the European countries protected by constitutions and international conventions on labour and social rights. However, these international conventions mainly contain mere declarations to only pursue the right to strike and do not have an effective protection mechanism. Nevertheless, in the last few decades a human rights perspective on labour law gained ground and thus international organizations and international courts started to derive labour rights like the right to strike from civil and political rights and therefore some of these labour rights enjoy the same level of protection as the first generation human rights. In its recent judgements, the European Court of Human Rights stated that the right to strike is protected under Article 11 of the European Convention on Human Rights and developed a case law on the requirements of a lawful strike action, secondary strike actions and the restrictions of the right to strike.

128 A Tanács rendelete a kollektív fellépéshez való jognak a letelepedés szabadságával és a szolgáltatásnyújtás szabadságával összefüggésben való gyakorlásáról (Javaslat), 2. cikk. COM(2012) 130 végleges, 19. 